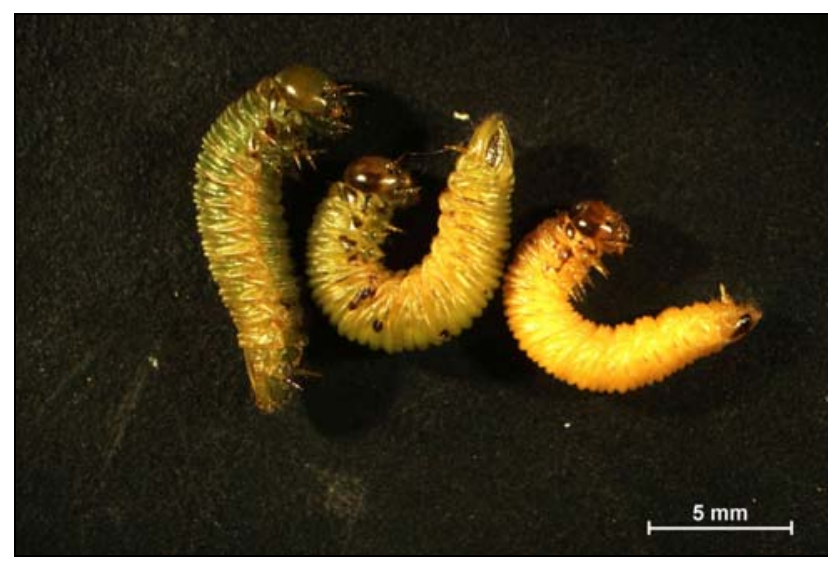

Slika 4: Morfološka variabilnost nabranih ličink (vzorec je bil nabran 10.7.2009)

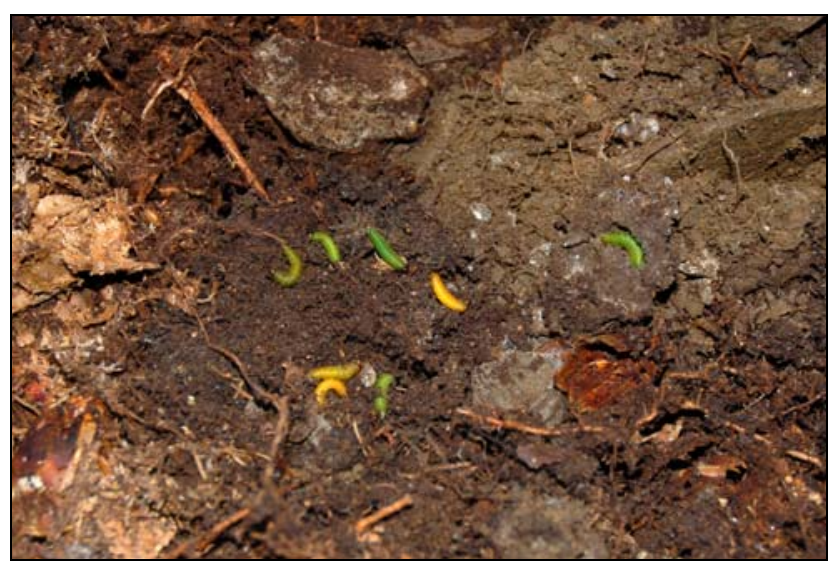

Slika 5: Iz števila osebkov pronimf, ki prezimijo v tleh, lahko sklepamo o velikosti populacij vrst rodu Cephalcia ter napovemo defoliacijo (slikano 18.8.2009)

\title{
Osip smrekovih iglic, Lirula macrospora
}

\section{Tine HAUPTMAN ${ }^{1 *}$, Marijan DENŠA ${ }^{2}$}

Osip smrekovih iglic, ki ga povzroča gliva Lirula macrospora (R. Hartig) Darker, je v letošnjem letu prizadel območje OE Nazarje, simptome bolezni pa smo opazili tudi v drugih delih Slovenije. Gliva spomladi okužuje letošnje, lahko pa tudi lanskoletne iglice, ki po okužbi sprva porumenijo in kasneje porjavijo (slika 1). $\mathrm{Na}$ odmrlih iglicah se najprej razvijejo piknidiji anamorfa Hypodermina hartigii Hilitzer, ki so $\mathrm{v}$ obliki mehurčkov (slika 2). Piknidiji vsebujejo veliko število 2,5-3,5 × 1,5-2,5 $\mu \mathrm{m}$ velikih konidijev, ki pa za širjenje bolezni nimajo pomena (imajo funkcijo spermacijev). Kasneje, odvisno od vremenskih razmer, se na iglicah razvijejo podolgovata, več $\mathrm{mm}$ dolga spolna trosišča - histeroteciji (slika 3), ki so najprej rjave kasneje pa črne barve. V njih nastajajo aski (slika 4) z nitastimi askosporami, ki spomladi ponovno povzročajo nove okužbe. Značilni simptom okužbe z glivo Lirula macrospora so tudi črne linije $\mathrm{v}$ obliki obročka na osnovi okuženih iglic (slika 3). Na tem mestu se kopičijo fenolne substance, ki zaustavljajo proces odpadanja odmrlih iglic. Zato odmrle iglice še dolgo ostanejo pritrjene na veji (Maček, 2008; Butin, 1995).
Gliva povzroča močnejše okužbe in s tem prezgodnje odmiranje iglic predvsem na vlažnih legah, bolj pa so občutljive iglice, ki so premalo osvetljene. Tako najpogosteje prizadene podrasla drevesa, lahko pa tudi spodnje, zesenčene veje višjih dreves. Kljub vsemu bolezen ni gospodarsko pomembna in zato zatiranje navadno ni potrebno (Maček, 2008). Priporočamo redčenje mladja, saj se tako zmanjša vlažnost mikrorastišča in s tem verjetnost okužbe. Iglice tako dobijo več svetlobe in so zato odpornejše.

\section{Viri}

Butin H. 1995. Tree diseases and disorders. Causes, Biology and Control in Forest and Amenity Trees. Oxford, USA, Oxford Univ. Press: 261 str.

Maček J. 2008. Gozdna fitopatologija. Ljubljana, Zavod za gozdove Slovenije, Zveza gozdarskih društev Slovenije, Gozdarska založba: 448 str.

${ }^{1}$ Gozdarski inštitut Slovenije, Večna pot 2, 1000 Ljubljana; ${ }^{2 Z a v o d ~ z a ~ g o z d o-~}$ ve Slovenije, Območna enota Nazarje, Savinjska cesta 4, 3331 Nazarje *tine.hauptman@gozdis.si 


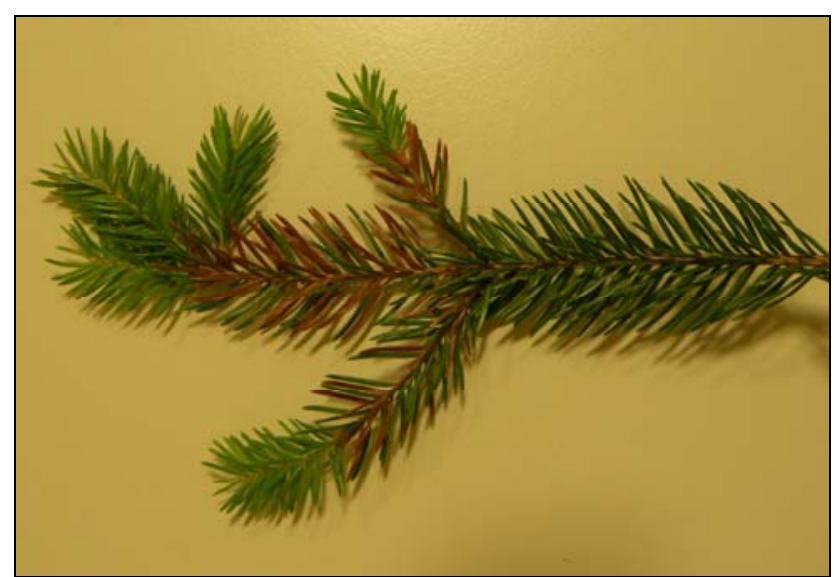

Slika 1: Odmrle lanskoletne iglice

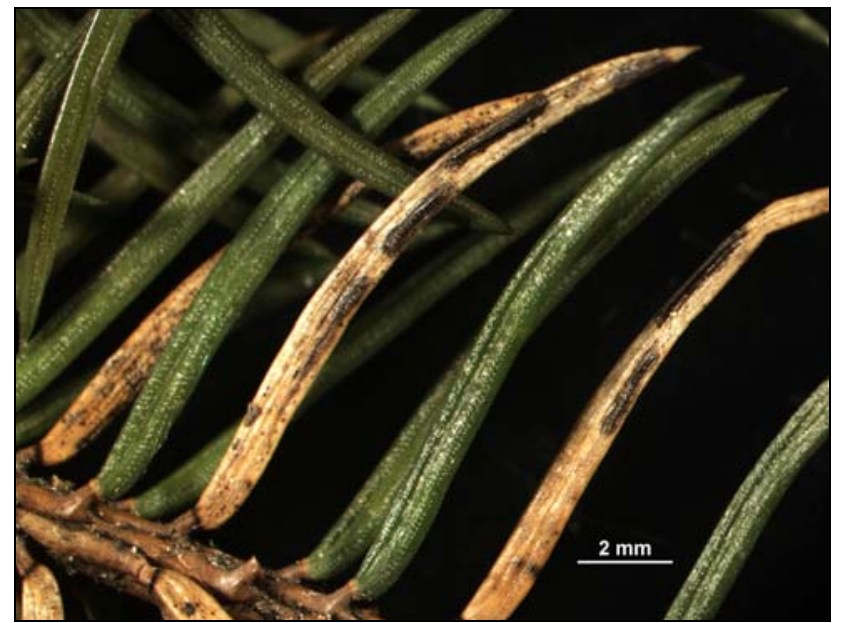

Slika 3: Podolgovati črni histeroteciji in črna obročkasta linija na osnovi okužene iglice

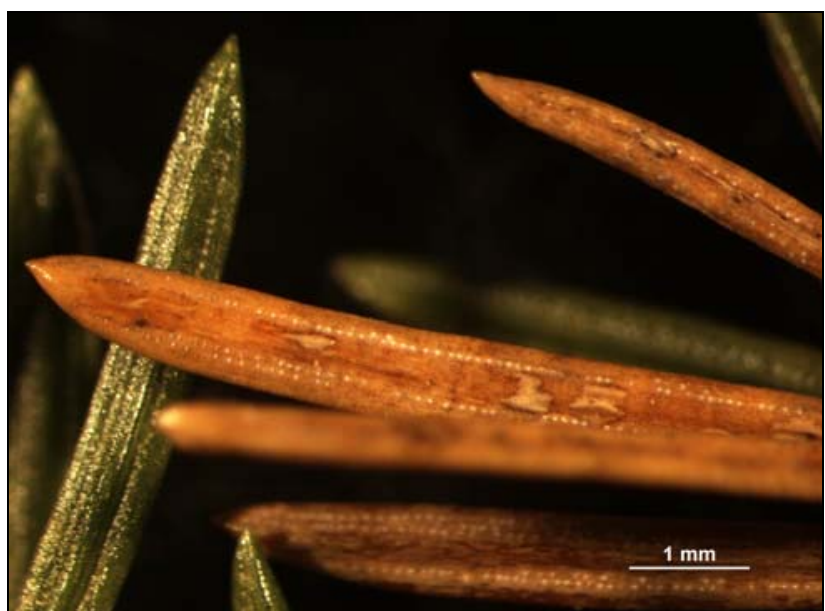

Slika 2: Piknidiji v obliki mehurčkov

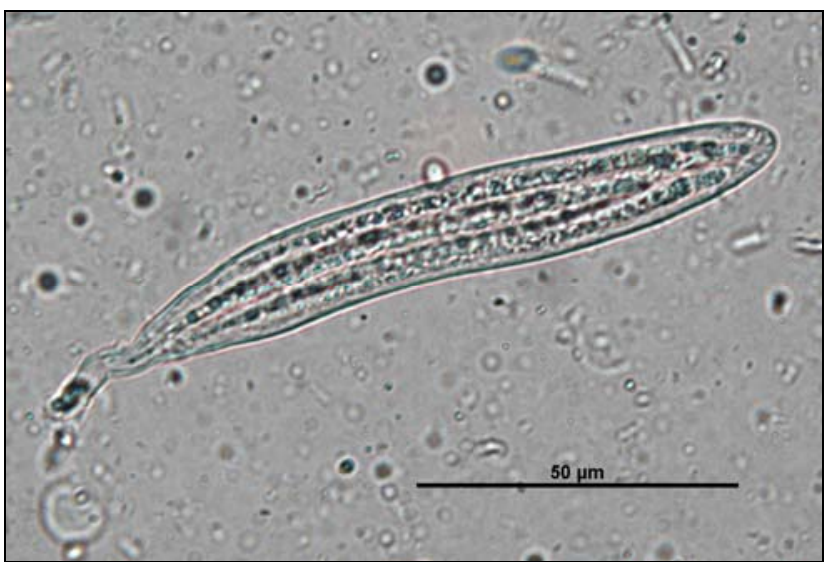

Slika 4: Ask z nitastimi askosporami 